\title{
Cytokine responses to allergens during the first 2 years of life in Estonian and Swedish children
}

\author{
Malin Fagerås Böttcher, Maria Jenmalm, Tia Voor, Kaja Julge, Patric Holt and Bengt \\ Björkstén
}

\section{Linköping University Post Print}

\section{Tweet}

N.B.: When citing this work, cite the original article.

This is the pre-reviewed version of the following article:

Malin Fagerås Böttcher, Maria Jenmalm, Tia Voor, Kaja Julge, Patric Holt and Bengt Björkstén, Cytokine responses to allergens during the first 2 years of life in Estonian and Swedish children, 2006, Clinical and Experimental Allergy, (36), 5, 619-628.

which has been published in final form at:

http://dx.doi.org/10.1111/j.1365-2222.2006.02484.x

Copyright: Wiley-Blackwell

http://eu.wiley.com/WileyCDA/Brand/id-35.html

Postprint available at: Linköping University Electronic Press

http://urn.kb.se/resolve?urn=urn:nbn:se:liu:diva-34820 


\title{
Cytokine responses to allergens during the first two years
}

\section{of life in Estonian and Swedish children}

\author{
Malin Fagerås Böttcher, $\mathbf{P h D}^{1}$ \\ Maria C Jenmalm, PhD ${ }^{1}$ \\ Tiia Voor, MD $^{2}$ \\ Kaja Julge, MD, $\mathrm{PhD}^{2}$ \\ Patrick G Holt, DSc, FRCPath ${ }^{3}$ \\ Bengt Björkstén, MD, $\mathrm{PhD}^{4}$
}

1. Department of Molecular and Clinical Medicine, Division of Paediatrics, Linköping University, Sweden

2. Children's Clinic of Tartu University Clinics, Tartu

3. Telethon Institute for Child Health Research, Perth, University of Western Australia

4. Institute of Environmental Medicine, Karolinska Institute, Stockholm, Sweden Dr Fagerås Böttcher and Dr Jenmalm contributed equally to this work. 


\begin{abstract}
Background: The prevalence of atopic disease among children in the formerly socialist countries in Europe, with a life style similar to that prevailing in Western Europe 30-40 years ago, is low, whereas there has been a pronounced increase in industrialised countries over the last decades. The environment during infancy influences the risk of developing allergy for many years, perhaps even for life.
\end{abstract}

Objective: To investigate the development of allergen specific cytokine responses during the first two years of life in two geographically adjacent countries with marked differences in living conditions and incidence of atopic diseases, i e Estonia and Sweden.

Methods: The development of immune responses to the food ( $\beta$-lactoglobulin (BLG) and ovalbumin) and inhalant (cat and birch) allergens were studied from birth up to the age of two years in 30 Estonian and 76 Swedish infants. Clinical investigation and skin prick tests were performed and blood samples obtained at birth and at 3, 6, 12 and 24 months.

Results: The levels of IL-5, IL-10 and IL-13 secreted by PBMC stimulated with BLG, ovalbumin and cat allergen in the Estonian and Swedish infants declined during the first 3 months of life. All cytokines then progressively increased in the Swedish infants, indicating the replacement of non specifically responding immature cord blood T-cells with specific T-memory cells, which are primed postnatally. The resurgence of allergenspecific responses in the Estonian infants was less marked. These differences were particularly notable for birch-specific T-cell responses, which correlated with development of atopic disease in the Swedish children. 
Conclusions: The development of specific T-cell memory to food and inhalant allergens during the first two years of life differs between infants living in Sweden and Estonia, and mirrors the disparate patterns of expression of allergic disease which subsequently develops in the respective populations.

Key words; Immune responses, infants, allergens, cytokines, atopic disease, Sweden, Estonia 


\section{Introduction}

The immune functions in children who later develop allergy and in those who remain non-allergic differ in several aspects [1]. The early immunoglobulin (Ig)E responses to allergens are eventually down regulated in infants who remain non-allergic, whereas they reach higher and more persistent levels in those who develop allergy [2]. Atopic diseases are generally characterised by excessive T-helper (Th)2-like immunity to allergens, with high production of interleukin (IL)-4 [3, 4], IL-5 [4, 5], IL-9 [4] and IL$13[4,6]$, accompanied by decreased [3] or similar [4-6] production of interferon (IFN)$\gamma$. Although allergen specific Th1-like immune responses are present in healthy individuals, IFN- $\gamma$ associated delayed type hypersensitivity is not observed. Therefore, factors counteracting Th1 like reactions are likely to be present and the antiinflammatory cytokine IL-10 may be one such candidate [7]. Interleukin-10 also suppresses IgE production [8] and counter-regulates Th2-like immunity [9].

Several factors, including environmental factors, influence the development of the specific cytokine profile, and the immune response pattern is thought to be set during early childhood $[10,11]$. The cytokine profile is more easily affected by external influences in naïve than in established responses [12], emphasizing the importance of events occurring during early childhood in determining responder phenotype in later life.

The prevalence of atopic disease among children in the formerly socialist countries in Europe, with a life style similar to that prevailing in Western Europe 30-40 years ago, is still low $[13,14]$, whereas there has been a pronounced increase in industrialized 
countries over the last decades [15]. After the German reunification in 1990, the prevalence of hay fever and atopic sensitisation has increased in children in the former East Germany [16]. The unification has been associated with tremendous changes in everyday life towards Western conditions in the former East Germany. Although the causes of the increase of atopic diseases in Western Europe are unknown, several factors associated with a Western lifestyle, e g smaller family size [17], Western diet [18] and an overall diminished exposure to environmental microorganisms $[19,20]$ have been proposed as potential explanations. We have reported differences in the composition of the gut flora in Estonian and Swedish children [21], and also that microflora associated characteristics were disturbed in the gut from children with atopic disease [11]. Furthermore, we found differences in the gut flora as early as at five days of age between infants who did or did not develop atopic disease during the first two years of life [22].

Little is known regarding eventual regional differences in the setting of immune response patterns. Renz et al has reported dominating Th0-responses, defined as IFN- $\gamma$ and IL-4/IL-5 secretion induced by phorbol myristate acetate (PMA) plus ionomycin in children growing up in Eastern Germany [23]. This was irrespective of their atopic status and age. The T-cell immune profile was age dependent in the children from Western Germany, with Th1- or Th2-responders dominating in the younger children (67 years) and Th0-responders dominating among the older children (9-11 years). Among the West German children, atopic disease was associated with a Th2-like cytokine profile. Strikingly, approximately one third of the children growing up in Western Germany was defined as non-responders, i e no detectable PMA plus ionomycin 
induced IFN- $\gamma$, IL-4 or IL-5 responses, irrespective of age, whereas less then $1 \%$ of the children growing up in Eastern Germany were non-responders. However, comparative studies on allergen-specific T-cell responses in children living in industrialized and less developed countries with a high and low prevalence of atopic disease, respectively, have not been performed. In particular, the prospective development of T-cell responses have not been studied in these environments during the first years of life, when events critical for the establishment of persistent atopic disease are likely to occur.

The aim of the present study was to investigate the development of allergen specific cytokine responses during the first two years of life in two geographically adjacent countries with marked differences in living conditions and incidence of atopic diseases, i e Estonia and Sweden. 


\section{Material and Methods}

\section{Study group}

The study comprises 30 Estonian children born during February 1997 - June 1998 at the Tartu University Women's' Clinic and 76 Swedish children born during March 1996 October 1999 at the Linköping University Hospital. The children participated with their families in a larger prospective study regarding the influence of the environment on development of allergic diseases in children, described in detail elsewhere [24]. Inclusion in this study was based on availability of mononuclear cells, isolated from peripheral blood from the children.

At 3, 6, 12 and 24 months of age, the parents answered questionnaires regarding allergic symptoms and environmental factors, $e g$ infections and diet. A pediatrician examined the children at 3, 6, 12 and 24 months in Estonia and at 24 months in Sweden. An experienced allergy research nurse examined the Swedish children at 3 or 6 and at 12 months. Atopic dermatitis was defined as pruritic, chronic or chronically relapsing noninfectious dermatitis with typical features and distribution. Asthma was defined as three or more episodes of bronchial obstruction during the last 12 months period, at least once verified by a physician. Allergic rhinitis/conjunctivitis was defined as rhinitis and/or conjunctivitis appearing at least twice within $1 \mathrm{~h}$ after exposure to a particular allergen and not related to infection. Urticaria was defined as allergic if it appeared at least twice within one hour after exposure to a particular allergen. The cumulative incidence of allergic disease up to two years of age was $10 \%(n=3)$ and $34 \%(n=25)$ among the Estonian and Swedish infants, respectively. One Estonian child was diagnosed with 
atopic dermatitis, one with atopic dermatitis and asthma and one child with asthma only. Among the 25 Swedish children with allergic disease, 24 had symptoms of atopic dermatitis and one had urticaria.

Skin prick tests (SPT) were performed at all follow-ups in duplicate on the volar aspects of the forearms with fresh skimmed cow's milk (lipid concentration $0.5 \%$ ) and thawed egg white. At 6, 12 and 24 months, the children were also tested with cat and dog allergen extracts and in Estonia also with mite allergen extract (Dermatophagoides pteronyssinus), at 12 months birch allergen extract was added to the panel and at 2 years timothy and in Estonia also cockroach (Blatella germanica) allergen. All extracts were standardised allergen extracts from ALK (Soluprick ${ }^{\circledR}$, ALK, Hørsholm, Denmark), execpt the cockroach extract, which was from Bayer, Spokane, WA, USA. Histamine hydrochloride, $10 \mathrm{mg} / \mathrm{ml}$, was used as positive and glycerol as negative control. The test was regarded as positive if the mean diameter of one of the wheals was at least $3 \mathrm{~mm}$. Seventeen \% $(n=5)$ of the Estonian and $37 \%(n=28)$ of the Swedish infants had at least one positive SPT up to two years of age (table 1). Two of the three Estonian infants with allergic disease up to two years of age had at least one positive SPT and the corresponding figure for the Swedish allergic infants was 19/25. These infants are referred to as infants with atopic disease.

\section{Isolation of peripheral blood mononuclear cells}

Venous blood samples were collected at birth (cord blood) and at all follow-ups in tubes with preservative-free heparin (Beckton Dickinson, Stockholm, Sweden). Peripheral blood mononuclear cells (PBMC) were isolated on Ficoll Paque density gradient 
(Pharmacia Biotech, Sollentuna, Sweden), and washed three times in RPMI-1640 (Life Technologies AB, Täby, Sweden) supplemented with $2 \%$ fetal calf serum (Life Technologies AB). The cells from both Estonian and Swedish children were cryopreserved by standard methodology in $10 \%$ DMSO (Sigma-Aldrich, Stockholm, Sweden), $50 \%$ fetal calf serum and $40 \%$ RPMI-1640. After cryopreservation, the cells collected from the Estonian infants were transported in liquid $\mathrm{N}_{2}$ to Linköping and stored there until analysis.

\section{Cell culture}

After thawing, the cells were resuspended at $1 \times 10^{6}$ viable cells $/ \mathrm{mL}$ AIM-V serum free medium (Life Technologies) supplemented with $20 \mu \mathrm{M}$ mercaptoethanol (SigmaAldrich). Duplicates of one $\mathrm{mL}$ aliquots $\left(1 \times 10^{6}\right.$ cells $)$ were cultured at $37^{\circ} \mathrm{C}$ with $5 \%$ $\mathrm{CO}_{2}$ with medium alone, $10000 \mathrm{SQU} / \mathrm{mL}$ Aquagen birch or cat extract (ALK), 100 $\mu \mathrm{g} / \mathrm{ml}$ of $\beta$-lactoglobulin or ovalbumin purified grade IV (Sigma-Aldrich) or $2 \mu \mathrm{g} / \mathrm{mL}$ phytohaemagglutinin (PHA) (Sigma-Aldrich). The endotoxin content in the birch extract was less than $0.5 \mathrm{EU} / \mathrm{mL}$ and $2.2 \mathrm{EU} / \mathrm{mL}$ in the cat extract as analysed by the chromogenic Limulus Amebocyte Lysate assay (Bio-Whittaker, Walkersville, ND, USA). The priority of the allergens was set as follows; birch, BLG, cat and last ovalbumin. After $24 \mathrm{~h}$ and 6 days, the cultures were centrifuged at $400 \mathrm{x}$ g for 5 minutes, and the supernatants were aspirated and stored in aliquots at $-20^{\circ} \mathrm{C}$. Allergen induced IL-10 and PHA induced IL-4, -5, -9, -10, -13 and IFN- $\gamma$ secretion was analysed in the $24 \mathrm{~h}$ cultures, and allergen induced IL-5, $-9,-13$ and IFN- $\gamma$ was analysed in the 6day cultures. To enable measurement of allergen induced IL-4 secretion, separate 6-day 
cultures were performed with a monoclonal antibody to the human IL-4 receptor; 2 $\mu \mathrm{g} / \mathrm{mL}$ (clone 25463.111, R\&D Systems, Abingdon, UK) [25].

\section{Cytokine analysis}

The levels of IL-4, -5, -9, IFN- $\gamma$ [4], IL-10 and IL-13 [11] were analysed as described in detail elsewhere. Values were expressed as $\mathrm{pg} / \mathrm{ml}$ deduced from a standard curve. The sensitivity limits for quantitative determinations were $2 \mathrm{pg} / \mathrm{mL}$ for IL-13 and IL-4, 4.7 $\mathrm{pg} / \mathrm{mL}$ for IL-10, $6.3 \mathrm{pg} / \mathrm{mL}$ for IL-5, $8 \mathrm{pg} / \mathrm{mL}$ for IL-9 and $25 \mathrm{pg} / \mathrm{mL}$ for IFN- $\gamma$. Samples below the sensitivity limit were given half the cut off value for statistical analyses.

\section{Statistics}

As the cytokine levels were not normally distributed even after logarithmic transformation, non-parametric tests, corrected for ties, were used. Comparisons between paired groups were performed with Wilcoxon signed rank test and between unpaired groups with Mann-Whitney $U$-test. A probability level of $<5 \%$ was considered to be statistically significant. Calculations were performed with a statistical package StatView 5.0 for PC (SAS Institute Inc., Cary, NC, USA).

\section{Ethics}

The Regional Committee for Human Research at the University Hospital of Linköping and the Ethics Review Committee on Human Research of the University of Tartu approved the study. 


\section{Results}

Interferon- $\gamma$, IL-5, IL-10 and IL-13 secretion from cord blood mononuclear cells $(\mathrm{CBMC})$ was frequently detected in response to the food allergens BLG (fig 1) and ovalbumin (data not shown), and to the perennial inhalant allergen cat dander (fig 2). The levels were similar in Estonian and Swedish newborns. Interleukin-5, IL-10 and IL13 responses decreased or tended to do so during the first three months of life both in Estonian and Swedish infants (fig 1-2). Cytokine responses from CBMC to the seasonal allergen birch were uncommon, except for IL-13, and the levels were low during the first six months in both Estonian and Swedish infants (fig 3). There was no association between month of birth and birch induced cytokine responses.

After three months of age, IFN- $\gamma$, IL-5, IL-10 and IL-13 secretion from PBMC in response to all allergens increased in the Swedish infants (fig 1-3). The responses remained low in the Estonian infants, however (fig 1-3). From 6 months, cat allergen (fig 2), and from 12 months of age, birch allergen (fig 3) induced IFN- $\gamma$, IL-5, -10 and 13 secretion was, or tended to be, higher in Swedish than in Estonian infants. Similar trends were observed for BLG induced IFN- $\gamma$, IL-5, -10 and -13 secretion (fig 1). The differences remained when comparing Swedish children with and without atopic disease with the Estonian children (data not shown). The number of Estonian children whose cells were stimulated with ovalbumin was too low ( $\mathrm{n} \leq 4$ at all ages) to enable statistical comparisons between the groups. 
Allergen induced IL-4 and IL-9 secretion was only sporadically detected and was generally low both in Estonian and Swedish infants (data not shown). Allergen induced IL-9 secretion increased or tended to do so during the first 24 months in the Swedish children, however (for birch see fig 4). No differences were observed between the two groups regarding allergen induced IL-4 secretion, whereas allergen induced IL-9 secretion tended to be higher among the Swedish children after the age of 12 months (data not shown).

Phytohaemagglutinin stimulation was used as a positive control and viability check of the cells. PHA induced cytokine secretion were generally similar in Estonian and Swedish infants (table 2). The PHA induced IFN- $\gamma$ secretion from CBMC was higher in Estonian (median=488, range:12-4191 (pg/ml)) than in Swedish (median=110 range:12$4166(\mathrm{pg} / \mathrm{ml}))$ children $(\mathrm{p}=0.036)$, however, whereas PHA induced secretion of IFN- $\gamma$, IL-4, IL-5, -9, -10 and -13 often was, or tended to be, higher in the Swedish infants at 24 months of age.

Birch induced cytokine responses were generally higher in Swedish infants with, as compared to without, atopic disease (fig 4). The differences reached statistical significance for IFN- $\gamma$ at 6 and 12 months, for IL-4 at 24 months, IL-5 and IL-13 at 12 months and IL-9 at 6 and 12 months. Similar trends were observed for birch induced IL5 at 24 months, IL-10 at 6 and 12 months and IL-13 at 6 and 24 months. The cytokine responses induced by the other allergens, $i$ e BLG, cat and ovalbumin, were similar among Swedish children with and without atopic disease at all ages. However, high IL4 and IL-5 responses to BLG were observed in milk SPT positive children at 24 months 
of age, with a similar trend for IL-13 (table 2). At 12 months of age, milk sensitized children showed low BLG induced IFN- $\gamma$ production (table 3). Since ovalbumin stimulated cultures were available from fewer children, findings for this allergen did not reach statistical significance. The low number of Estonian children with allergic disease and/or positive SPT makes statistical comparisons within this group unreliable. No differences between allergic and non-allergic or SPT positive and negative children were observed among the Estonian children, however (data not shown). 


\section{Discussion}

Our findings in this prospective study show differences in the pattern of immune responses to allergens during the first two years of life in two geographically adjacent countries with marked differences in living conditions and incidence of atopic diseases, $i$ e Estonia and Sweden. Notably, the levels of IL-5, IL-10 and IL-13 secreted by PBMC stimulated with BLG, ovalbumin and cat allergen in the Estonian and Swedish infants declined during the first 3 months of life. All cytokines then progressively increased in the Swedish children. The biphasic response pattern in the Swedish children is consistent with progressive replacement of non specifically responding immature fetal T-cells with specific T-memory cells, which are primed postnatally. This suggests that priming of long lived Th-memory cells may occur during this period, and this possibility is consistent with recent studies $[10,11]$. These and other studies have reported the presence of allergen-responsive T-cells in cord blood, raising the possibility that T-cell priming may in some cases occur transplacentally [26]. However, more recent studies on the nature of T-cell responses to environmental allergens in newborns indicate that the bulk of responding cells represent functionally immature recent thymic emigrants (RTE), as opposed to conventional Th-memory cells [27]. The T-cell receptors utilised by RTE are structurally different to those on mature naive or memory T-cells [28], and facilitate promiscuous low affinity reactions to a wide range of peptides, triggering an initial burst of cytokine production followed by rapid apoptosis, in some cases accompanied by bystander activation of regulatory T-cells [27]. As these RTE progressively die out during early childhood, they are presumably replaced by functionally mature naïve $\mathrm{T}$-cells with the capacity to generate genuine 
memory responses. In support of this, cytokine responses to BLG, cat and birch declined between birth and 6 months and were then followed by resurgence up to two years in the Swedish children. This was most marked with the important seasonal inhalant allergen birch. Skin test reactivity to milk was associated with high BLG induced Th2-like responses to BLG at 24 months of age, and low IFN- $\gamma$ responses at 12 months, in accordance with previous studies showing enhanced Th2-like responses to milk in sensitized children [29]. T-cell responses to birch correlated strongly with development of atopic disease in the Swedish children, with high IFN- $\gamma$ responses at 6 and 12 months and high Th2-like responses from 12 months onwards in children with atopic disease.

We believe that the responses are allergen specific, although the allergen extracts are not endotoxin free, since we have earlier reported that immune responses to birch extract are related to birch allergy [11] and that cells from birch or cat sensitised children respond with Th2 like cytokine production after stimulation with birch or cat allergen extract, but not after stimulation with an unrelated allergen [4].

In contrast to the biphasic responses in the Swedish children, the resurgence of allergenspecific responses in the Estonian infants was much less marked, although the cells responded well to mitogenic PHA stimulation. Regardless of presence of atopic disease, the Swedish children showed a different development of cytokine responses to allergens than the Estonian children. Thus, the findings were similar both when comparing Estonian infants with Swedish allergic and non-allergic infants. In Estonia, there were 
too few allergic children to allow any comparison between allergic and non-allergic individuals.

In a smaller long-term prospective study of development of immune responses to birch in Swedish children over the first seven birch pollen seasons, we have previously demonstrated that a transient early Th2-like response is down-regulated after the third pollen season, except in children who develop clinical allergy to the particular allergen [11]. It will be interesting to continue to follow the cohorts of the present study up to the age when clinical allergy to birch commonly develops.

The similar immune responses to allergens during the first 3-6 months of age in Estonian and Swedish infants indicate that differences in the environments of the two countries do not affect the very early immune responses. After that age, Swedish infants displayed stronger immune responses to all allergens than Estonian infants, and the responses included both Th1 and Th2 cytokines. We and others have previously hypothesized that the increase in prevalence and severity of atopic diseases during the last decades in industrialized countries is due to reduced maturation of Th1-like immunity to allergens, as a consequence of reduced microbial stimulation [20]. However, the simultaneous increases in the incidence of both allergic disorders, inflammatory bowel disease and autoimmune diseases in industrialised countries [30], and the low prevalence of autoimmune disease in less developed countries [31] may indicate that this is too simplified a theory and suggests a broader defect in immune regulation. For example, diseases associated with dysfunctional immune responses may be explained by an imbalance of effector $\mathrm{T}$ cells and regulatory $\mathrm{T}$ cells $[32,33]$. Recent 
studies suggest that regulatory $\mathrm{T}$ cells are important for the development of tolerance to allergens $[34,35]$. Speculatively, the lower Th1 and Th2 cytokine production in the Estonian infants up to the age of two years could thus be explained by a more rapid induction of T-cell regulation. As regulatory T cells can be activated by microbial products to exert suppression [36] and their development may be particularly favored by the environment at the Peyer's patches in the gut [37], the less diverse gut flora of Swedish, as compared to Estonian, children [21, 22], may cause a less efficient induction of regulatory $\mathrm{T}$ cells. Unfortunately, we could not investigate this possibility as the study was designed at a time when the potential role of regulatory $\mathrm{T}$ cells was not fully appreciated.

In conclusion, the development of specific immune responses to food and inhalant allergens during the first two years of life differs between infants living in a country with a low and a high prevalence of allergy. Thus, both Th1 and Th2 cytokine production is lower in response to allergen stimulation in Estonian infants after 6 months of age, suggesting a more rapid induction of immune regulation. 


\section{Acknowledgements}

We thank Ulrika Bengtsson, Dr Karel Duchén, Anne-Marie Fornander, Kerstin Hagersten, Lena Lindell and Kristina Warstedt, Division of Paediatrics, Linköping University, Sweden, and Tiina Rebane and Ülle Kuld from Children's Clinic of Tartu University Clinics, Estonia, for excellent technical assistance. We also thank Dr Jacques van Snick, Ludwig Institute for Cancer Research, Brussels Branch, Belgium for kindly providing antibodies to IL-9. The Swedish Research Council (grant No. 7510), the Swedish Foundation for Health Care Sciences and Allergy Research, the National Swedish Association against Allergic Diseases, the National Heart and Lung Association are acknowledged for financial support. 


\section{References}

1. Björkstén B. The intrauterine and postnatal environments. J Allergy Clin Immunol 1999;104:1119-1127.

2. Hattevig G, Kjellman B, Björkstén B. Appearance of IgE antibodies to ingested and inhaled allergens during the first 12 years of life in atopic and non-atopic children. Pediatr Allergy Immunol 1993;4:182-186.

3. Imada M, Estelle F, Simons R, Jay FT, HayGlass KT. Allergen-stimulated interleukin-4 and interferon-gamma production in primary culture: Responses of subjects with allergic rhinitis and normal controls. Immunology 1995;85:373-380.

4. Jenmalm MC, Van Snick J, Cormont F, Salman B. Allergen-induced Th1 and Th2 secretion in relation to specific allergen sensitization and atopic symptoms in children. Clin Exp Allergy 2001;31:1528-1535.

5. Till S, Dickason R, Huston D, Humbert M, Robinson D, Larché M, et al. IL-5 secretion by allergen-stimulated CD4+ T cells in primary culture: Relationship to expression of allergic disease. J Allergy Clin Immunol 1997;99:563-569.

6. Till S, Durham S, Dickason R, Huston D, Bungre J, Walker S, et al. IL-13 production by allergen-stimulated $\mathrm{T}$ cells is increased in allergic disease and associated with IL-5 but not IFN- $\gamma$ expression. Immunology 1997;91:53-57.

7. Akdis CA, Blesken T, Akdis M, Wütrich B, Blaser K. Role of interleukin 10 in specific immunotherapy. J Clin Invest 1998;102:98-106.

8. Punnonen J, de Waal Malefyt R, van Vlasselaer P, Gauchat J-F, de Vriers JE. IL-10 and viral IL-10 prevent induced IgE synthesis by inhibiting the accessory cell function of monocytes. J Immunol 1993;151:1280-1289. 
9. Yazdanbakhsh M, van den Biggelaar AHJ, Maizels RM. Th2 responses without atopy: immunoregulation in chronic helminth infections and reduced allergic disease. TRENDS Immunol 2001;22:372-377.

10. Prescott SL, Macaubas C, Smallacombe T, Holt BJ, Sly PD, Holt PG. Development of allergen-specific T-cell memory in atopic and normal children. Lancet 1999;353:196-200.

11. Böttcher MF, Jenmalm MC, Björkstén B. Immune responses to birch in young children during their first seven years of life. Clin Exp Allergy 2002;32:1690-1698.

12. Manetti R, Gewrosa F, Giudzi MG, Biagotti R, Parronchi P, Piccinni MP, et al. Interleukin 12 induces stable priming for intereferon $\gamma($ IFN- $\gamma)$ production during differentiation of human T helper (Th) cells and transient IFN- $\gamma$ production in established Th2 cell clones. J Exp Med 1994;179:1273-1283.

13. Bråbäck L, Breborowicz A, Julge K, Knutsson A, Riikjarv MA, Vasar M, et al. Risk factors for respiratory symptoms and atopic sensitisation in the Baltic area. Arch Dis Childhood 1995;72:487-493.

14. Commitee TISoAaAiCIS. Worldwide variation in the prevalence of rymptoms of asthma, allergic rhinoconjunctivitis, and atopic eczema: ISAAC. Lancet 1998;351:1225-1232.

15. Åberg N, Hesselmar B, Åberg B, Eriksson B. Increase of asthma, allergic rhinitis and eczema in Swedish schoolchildren between 1979 and 1991. Clin Exp Allergy $1995 ; 25: 815-819$.

16. von Mutius E, Weiland SK, Fritzsch C, Duhme H, Keil U. Increasing prevalence of hay fever and atopy among children in Leipzig, East Germany. The Lancet $1998 ; 351: 862-866$. 
17. Strachan DP. Hay fever, hygiene, and household size. Br Med J 1989;299:12591260.

18. Black PN, Sharpe S. Dietary fat and asthma: is there a connection? Eur Resp J 1997;10:6-12.

19. Holt PG. Environmental factors and primary T-cell sensitisation to inhalant allergens in infancy: reappraisal of the role of infections and air pollution. Pediatr Allergy Immunol 1995;6:1-10.

20. Holt PG, Sly PD, Björkstén B. Atopic versus infectious diseases in childhood: a question of balance? Pediatr Allergy Immunol 1997;8:53-58.

21. Björksten B, Naaber P, Sepp E, Mikelsaar M. The intestinal microflora in allergic Estonian and Swedish 2-year-old children. Clin Exp Allergy 1999;29:342-346.

22. Björksten B, Sepp E, Julge K, Voor T, Mikelsaar M. Allergy development and the intestinal microflora during the first year of life. J Allergy Clin Immunol 2001;108:516-520.

23. Renz H, von Mutius E, Illi S, Wolkers F, Hirsch T, Weiland SK. TH1/TH2 immune response profiles differ between atopic children in eastern western Germany. J Allergy Clin Immunol 2002;109:338-342.

24. Voor T, Julge K, Böttcher MF, Jenmalm MC, Duchén K, Björksten B. The development of atopic sensitization and atopic dermatitis during the first two years of life in Estonian and Swedish children. Clin Exp Allergy 2005;35:153-9.

25. Ekerfelt K, Ernerudh J, Jenmalm MC. Detection of spontaneous and antigeninduced human interleukin-4 responses in vitro: comparison of ELISPOT, a novel ELISA and real-time RT-PCR. J Immunol Methods 2002;260:55-67. 
26. Prescott SL, Macaubas C, Holt BJ, Smallacombe TB, Loh R, Sly PD, et al. Environmental allergens: Universal skewing of initial $\mathrm{T}$ cell responses toward the Th2 cytokine profile. J Immunol 1998;160:4730-4737.

27. Thornton CA, Upham JW, Wikström ME, Holt BJ, White GP, Sharp MJ, et al. Functional maturation of CD4+CD25+CTLA4+CD45RA+ T regulatory cells in human neonatal $\mathrm{T}$ cell responses to environmental antigens/allergens. J Immunol 2004; 173:3084-3092.

28. O'Neill RM, Hassan J, Reen DJ. IL-7 regulate homeostatic maintenance of recent thymic emigrants in association with caspase-mediated cell proliferation and apoptotic cell death. J Immunol 2003;170:4524-4531.

29. Schade RP, Van Ieperen-Van Dijk AG, Van Reijsen FC, Versluis C, Kimpen JLL, Knol EF, et al. Differences in antigen-specific T-cell responses between infants with atopic dermatitis with and without cow's milk allergy: relevance of $\mathrm{T}_{\mathrm{H}} 2$ cytokines. J Allergy Clin Immunol 2000;106:1155-1162.

30. Stene LC, Nafstad P. Relation between occurrence of type 1 diabetes and asthma. The Lancet 2001;357:607-608.

31. Onkamo P, Väänänen S, Karvonen M, Tuomilehto J. Worldwide increase in the incidence of Type I diabetes - the alanysis of the data on published incidence trends. Diabetologia 1999;42:1395-1403.

32. Sakaguchi S. Naturally arising CD4+ regulatory T cells for immunologic selftolerance and negative control of immune responses. Ann Rev Immunol 2004;22:531-562.

33. O'Garra A, Vieira P. Regulatory T cells and mechanisms of immune system control. Nature Medicine 2004;10:801-805. 
34. Akdis M, Verhagen J, Taylor A, Karamaloo F, Karagiannidis C, Crameri R, et al. Immune responses in healthy and allergic individuals are characterized by a fine balance between allergen-specific T regulatory 1 and T helper 2 cells. J Exp Med 2004; 199:1567-1575.

35. Karlsson MR, Rugtveit J, Brandzaeg P. Allergen-responsive CD4+CD25+ regulatory T cells in children who have outgrown cow's milk allergy. J Exp Med 2004;199:1679-1688.

36. Caramalho I, Lopes-Carvalho T, Ostler D, Zelenay S, Haury M, Demengeot J. Regulatory T cells selectively express toll-like receptors and are activated by lipopolysacharide. J Exp Med 2003;197:403-411.

37. Jump RL, Levine AD. Murine Peyer's patches fovor development of an IL-10 secreting, regulatory T cell population. J Immunol 2002;168:6113-6119. 


\section{Abbreviations}

BLG $\quad \beta$-lactoglobulin

CBMC cord blood mononuclear cells

IFN interferon

Ig immunoglobulin

IL interleukin

PBMC peripheral blood mononuclear cells

PHA phytohaemagglutinin

PMA phorbol myristate acetate

RTE recent thymic emigrants

SPT skin prick test

Th T-helper 


\begin{tabular}{|l|l|l|}
\hline \multicolumn{2}{|l|}{ Table 1. Cumulative incidence of skin prick test positivity up to two years of age } \\
\hline & Estonian & Swedish \\
\hline Any SPT & $5 / 30(17 \%)$ & $28 / 75(37 \%)$ \\
\hline Egg white & $3 / 28(11 \%)$ & $24 / 76(32 \%)$ \\
\hline Cow's milk & $1 / 30(3 \%)$ & $7 / 75(9 \%)$ \\
\hline Cat allergen & $2 / 30(7 \%)$ & $4 / 75(5 \%)$ \\
\hline Birch allergen & $0 / 30(0 \%)$ & $7 / 75(9 \%)$ \\
\hline
\end{tabular}




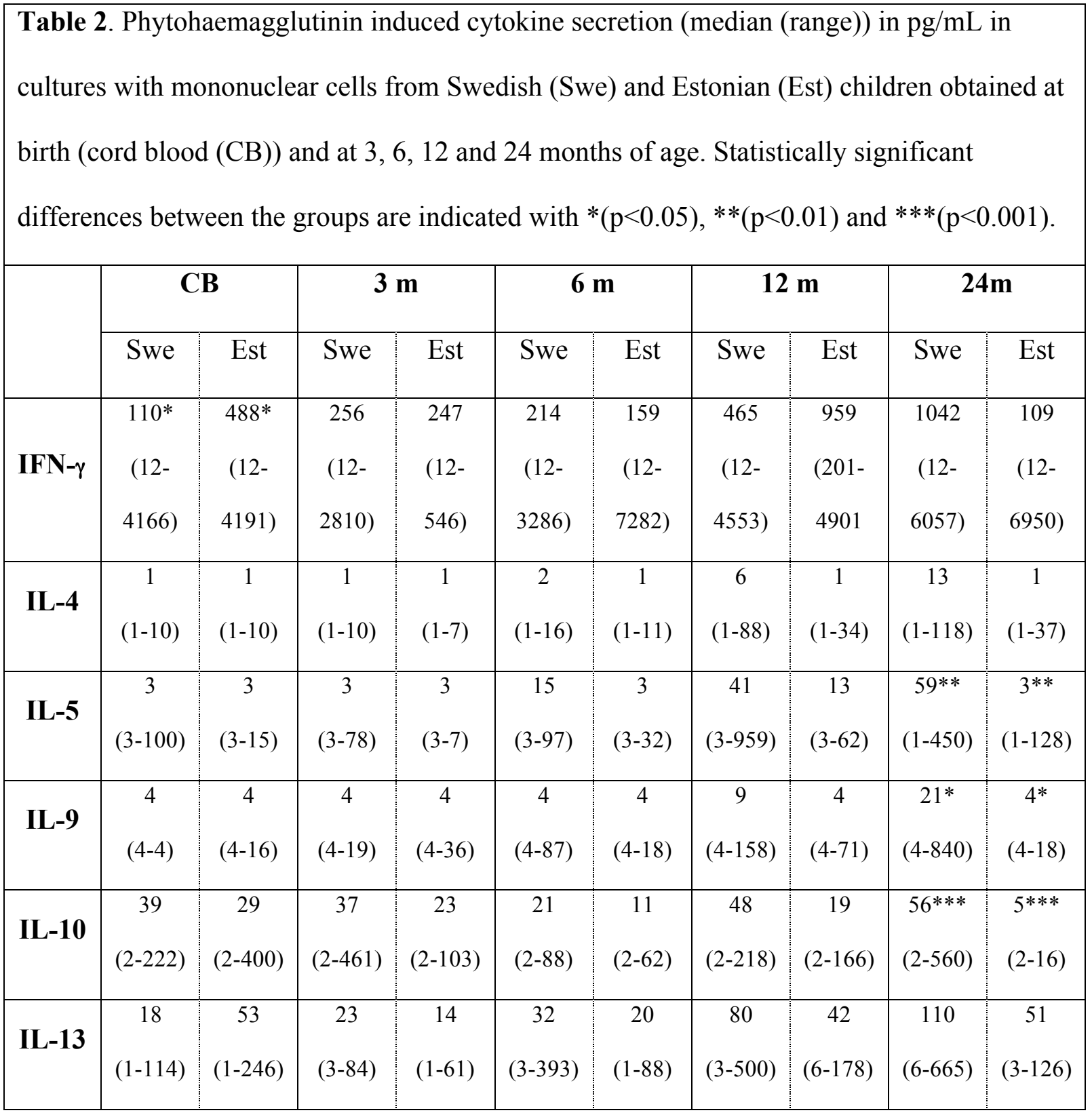




\begin{tabular}{|c|c|c|c|c|}
\hline \multicolumn{5}{|c|}{$\begin{array}{l}\text { Table 3. Cytokine levels (median (range), } \mathrm{pg} / \mathrm{mL} \text { ) after stimulation with } \\
\text { BLG in relation to milk sensitisation, at } 12 \text { months for IFN- } \gamma \text { and } 24 \text { months } \\
\text { for IL-4, IL-5 and IL-13. }{ }^{*} \mathrm{p}<0.05 \text { (Mann-Whitney U-test). }\end{array}$} \\
\hline \multicolumn{5}{|c|}{\begin{tabular}{l|l|l|l|l} 
& Milk SPT + & $\mathrm{n}$ & Milk SPT- & $\mathrm{n}$
\end{tabular}} \\
\hline IFN- $\gamma$ & $12(12-55)^{*}$ & 6 & $39(12-1610)$ & 60 \\
\hline IL-4 & $3(1-6)^{*}$ & 6 & $1(1-5)$ & 34 \\
\hline IL-5 & $55(7-271)^{*}$ & 8 & $10(3-140)$ & 54 \\
\hline IL-13 & $50(1-1721)^{\mathrm{p}=0.09}$ & 8 & $19(1-240)$ & 54 \\
\hline
\end{tabular}




\section{Legends to figures}

\section{Figure 1.}

$\beta$-lactoglobulin induced IFN- $\gamma$, IL-5, -10 and -13 secretion from mononuclear cells isolated from cord blood (CB) or peripheral blood obtained at 3, 6, 12 and 24 months of age from Swedish (open circles) and Estonian (filled circles) infants. The cytokine levels are expressed in $\mathrm{pg} / \mathrm{mL}$ and the median values are indicated. Statistical comparisons between the Estonian and Swedish groups were performed with Mann-Whitney $U$-test. Statistically significant differences are marked in bold and trends in plain text. The age related changes was calculated with Wilcoxon signed rank test and are indicated below each figure. The data was compared as follows, CB with 3 or 6 months data, 3 or 6 months with 12 months data and 12 months with 24 months data.

\section{Figure 2.}

Cat allergen induced IFN- $\gamma$, IL-5, -10 and -13 secretion from mononuclear cells isolated from cord blood (CB) or peripheral blood obtained at 3, 6, 12 and 24 months of age from Swedish (open circles) and Estonian (filled circles)infants. The cytokine levels are expressed in $\mathrm{pg} / \mathrm{mL}$ and the median values are indicated. Statistical comparisons between the Swedish and Estonian groups were performed with Mann-Whitney $U$-test. Statistically significant differences are marked in bold and trend in plain text. The age related changes was calculated with Wilcoxon signed rank test and are indicated below each figure. The data was compared as follows, $\mathrm{CB}$ with 3 or 6 months data, 3 or 6 months with 12 months data and 12 months with 24 months data. 


\section{Figure 3.}

Birch allergen induced IFN- $\gamma$, IL-5, -10 and -13 secretion from mononuclear cells isolated from cord blood $(\mathrm{CB})$ or peripheral blood obtained at 3, 6, 12 and 24 months of age from Swedish (open circles) and Estonian (filled circles) infants. The cytokine levels are expressed in $\mathrm{pg} / \mathrm{mL}$ and the median values are indicated. Statistical comparisons between the Estonian and Swedish groups were performed with Mann-Whitney $U$-test. Statistically significant differences are marked in bold and trend in plain text. The age related changes was calculated with Wilcoxon signed rank test and are indicated below each figure. The data was compared as follows, $\mathrm{CB}$ with 3 or 6 months data, 3 or 6 months with 12 months data and 12 months with 24 months data.

\section{Figure 4.}

Birch allergen induced cytokine secretion from Swedish infants without (open squares) and with (filled squares) atopic disease. Statistical comparisons between the groups were performed with Mann-Whitney $U$-test and statistically significant differences are marked in bold and trends in plain text. 
Fig 1

\section{BLG IFN- $\gamma$}

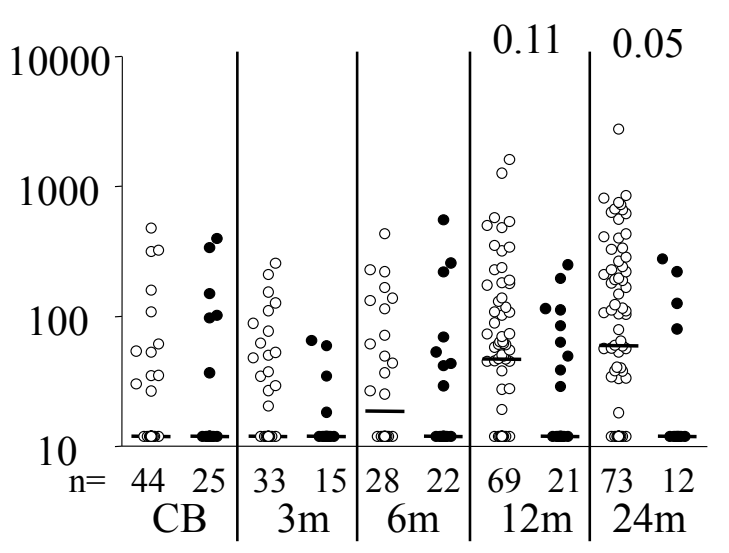

Swe

$\uparrow \mathrm{CB} \rightarrow 3 \mathrm{~m} p=0.01$
BLG IL-5

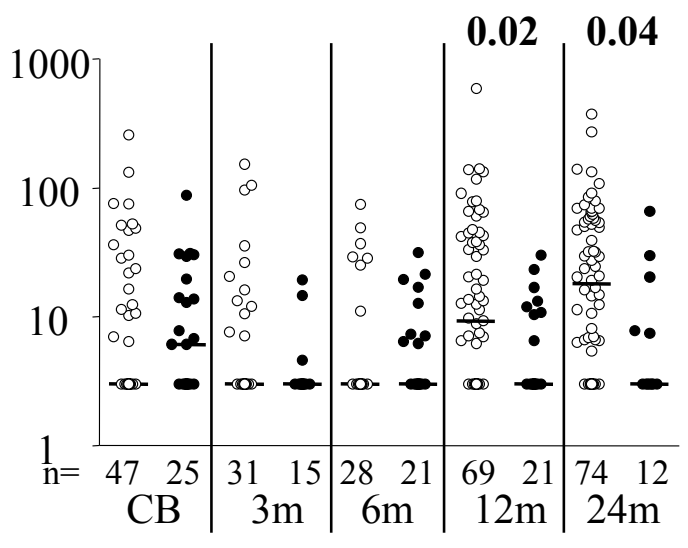

Est

$\downarrow \mathrm{CB} \rightarrow 3 \mathrm{~m} \mathrm{p}=0.09$

Swe

$\downarrow \mathrm{CB} \rightarrow 3 \mathrm{~m} p=0.02$

$\uparrow 3 \mathrm{~m} \rightarrow \mathbf{1 2 m}$ p $=\mathbf{0 . 0 4}$

$\uparrow 6 \mathrm{~m} \rightarrow 12 \mathrm{~m} \mathrm{p}=0.1$
BLG IL-10

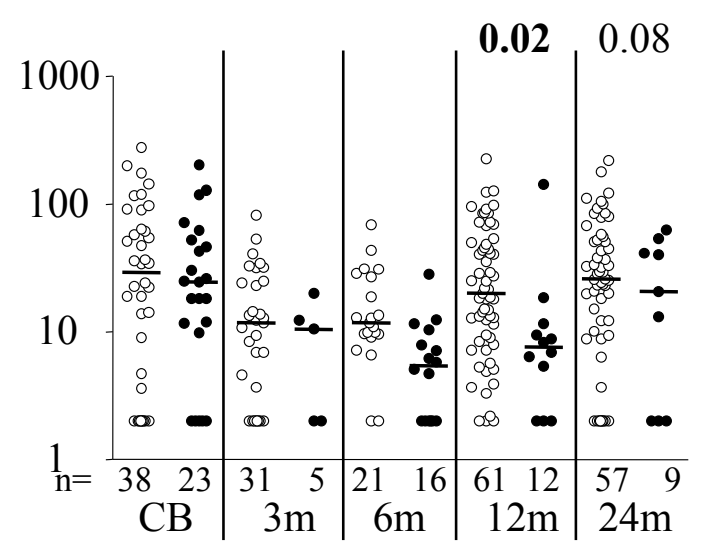

Est

$\downarrow \mathrm{CB} \rightarrow 3 \mathrm{~m} \mathrm{p}=0.1$

Swe

$\downarrow \mathrm{CB} \rightarrow 3 \mathrm{~m} \mathrm{p}=0.1$

$\downarrow \mathrm{CB} \rightarrow 6 \mathrm{~m} \mathrm{p}=0.1$

$\uparrow 3 \mathrm{~m} \rightarrow \mathbf{1 2 m} \mathbf{p}=\mathbf{0 . 0 2}$
BLG IL-13

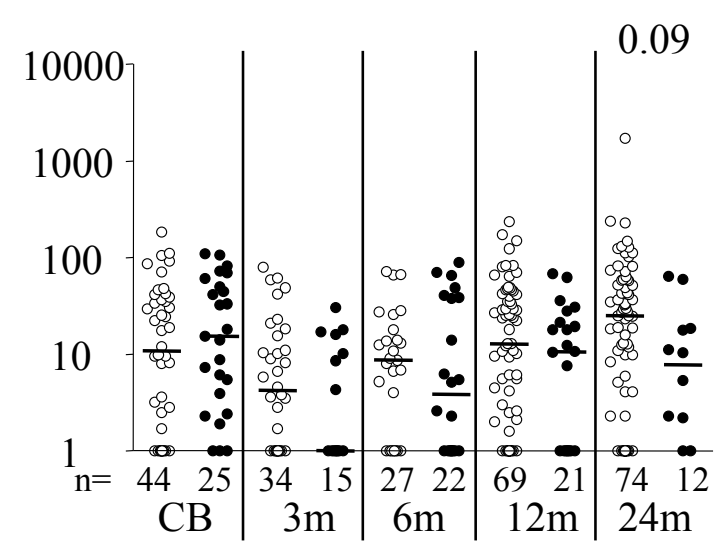

Est

$\downarrow \mathrm{CB} \rightarrow 3 \mathrm{~m} \mathrm{p}=\mathbf{0 . 0 0 3}$

Swe

$\downarrow \mathrm{CB} \rightarrow 3 \mathrm{~m}$ p $=0.04$

$\uparrow 3 \mathrm{~m} \rightarrow 12 \mathrm{~m} \mathrm{p}=0.05$ 
Fig 2

\section{Cat IFN- $\gamma$}

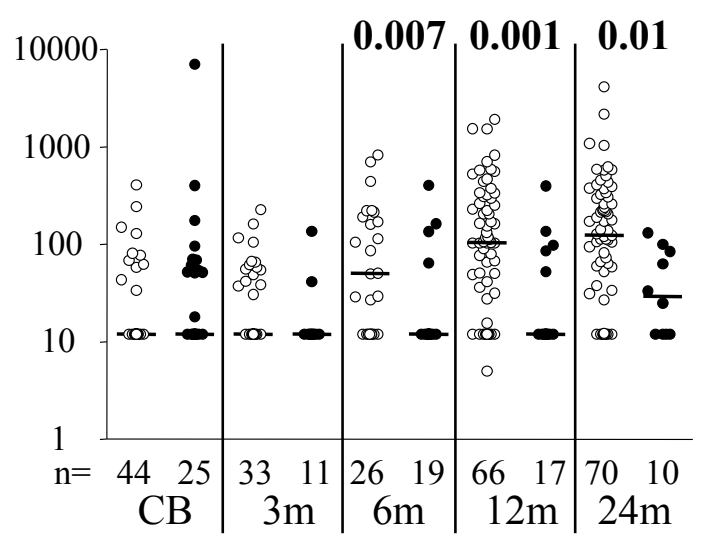

Est

$\downarrow \mathrm{CB} \rightarrow 3 \mathrm{~m} \mathrm{p}=0.08$

Swe

$$
\begin{aligned}
& \uparrow C B \rightarrow 6 m p=0.049 \\
& \uparrow 3 \mathrm{~m} \rightarrow 12 \mathrm{~m} p=0.0004 \\
& \uparrow 6 \mathrm{~m} \rightarrow 12 \mathrm{~m} p=0.04
\end{aligned}
$$

\section{Cat IL-5}

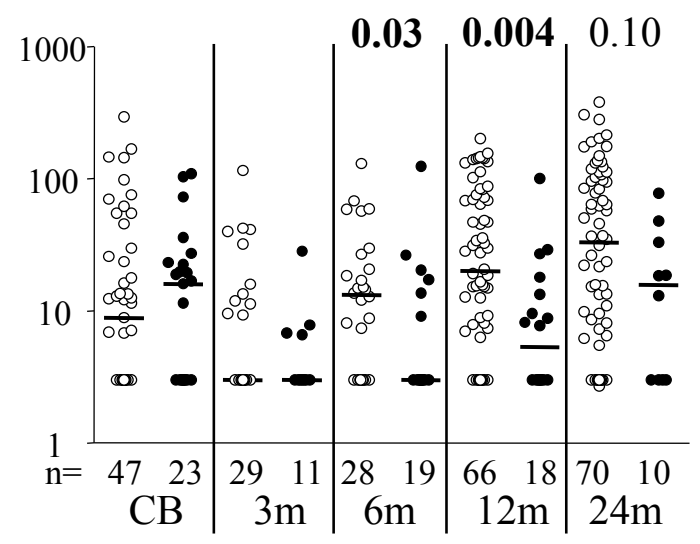

Est

$$
\downarrow \mathrm{CB} \rightarrow 3 \mathrm{~m} p=0.03
$$

Swe

$$
\begin{aligned}
& \downarrow \mathbf{C B} \rightarrow \mathbf{3 m} \mathbf{p}=\mathbf{0 . 0 0 8} \\
& \uparrow \mathbf{3 m} \rightarrow \mathbf{1 2} \mathbf{m} \mathbf{p}=\mathbf{0 . 0 0 1} \\
& \uparrow 6 \mathrm{~m} \rightarrow 12 \mathrm{~m} p=0.1 \\
& \uparrow 12 \mathrm{~m} \rightarrow 24 \mathrm{~m} p=0.08
\end{aligned}
$$

\section{Cat IL-10}

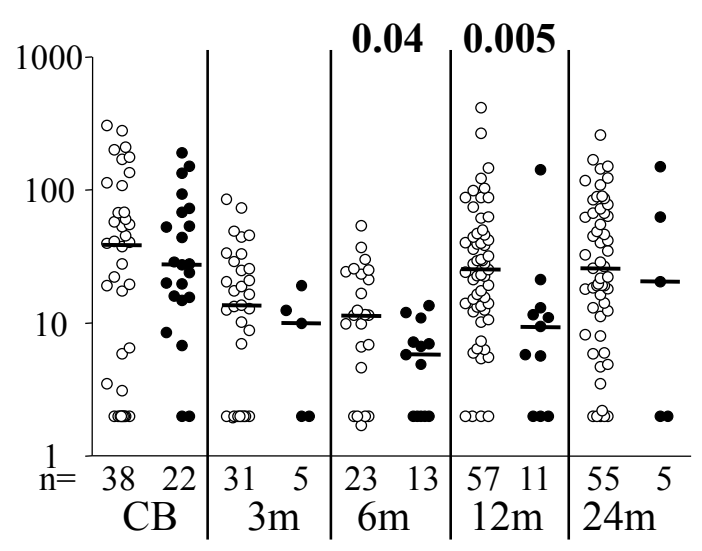

Est

$\downarrow \mathrm{CB} \rightarrow 3 \mathrm{~m} \mathrm{p}=0.1$

Swe

$$
\begin{aligned}
& \downarrow \mathrm{CB} \rightarrow 6 \mathrm{~m} \mathrm{p}=0.1 \\
& \uparrow \mathbf{3 m} \rightarrow \mathbf{1 2} \mathbf{m} \mathbf{p}=\mathbf{0 . 0 1} \\
& \uparrow 6 \mathrm{~m} \rightarrow 12 \mathrm{~m} p=0.06
\end{aligned}
$$

\section{Cat IL-13}

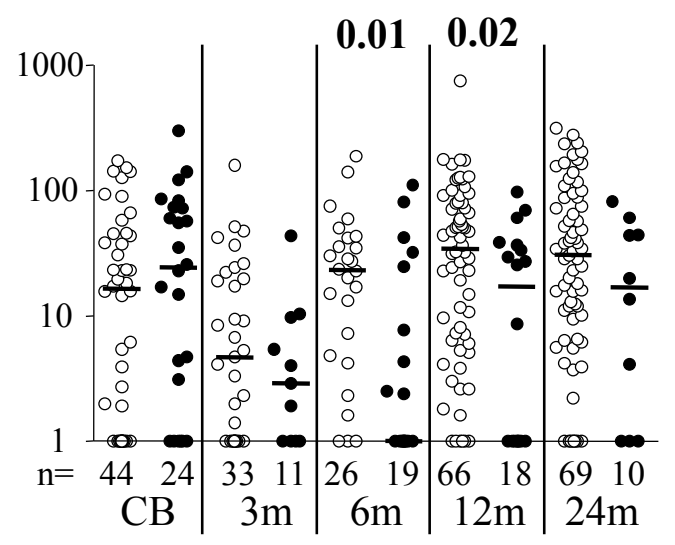

Est

$$
\begin{aligned}
& \downarrow \mathbf{C B} \rightarrow \mathbf{3 m} \mathbf{p}=\mathbf{0 . 0 2} \\
& \text { Swe } \\
& \downarrow \mathbf{C B} \rightarrow \mathbf{3 m} \mathbf{p}=\mathbf{0 . 0 0 2} \\
& \uparrow \mathbf{3 m} \rightarrow \mathbf{1 2} \mathbf{m} \mathbf{p}=\mathbf{0 . 0 0 1} \\
& \uparrow 6 \mathrm{~m} \rightarrow 12 \mathrm{~m} \mathrm{p}=0.05
\end{aligned}
$$


Fig 3

\section{Birch IFN- $\gamma$}

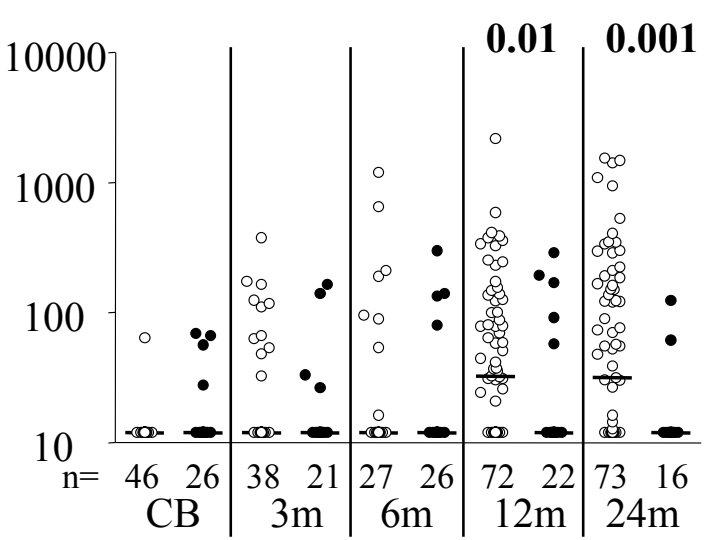

Swe

$\uparrow \mathrm{CB} \rightarrow 3 \mathrm{~m} \mathrm{p}=0.08$

$\uparrow 12 \mathrm{~m} \rightarrow 24 \mathrm{~m} p=0.006$
Birch IL-5

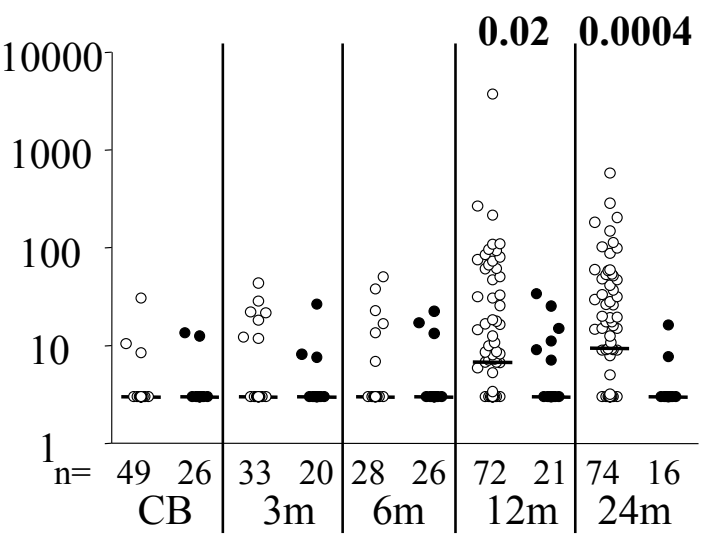

Swe

$\uparrow 3 m \rightarrow 12 m p=0.02$

\section{Birch IL-10}

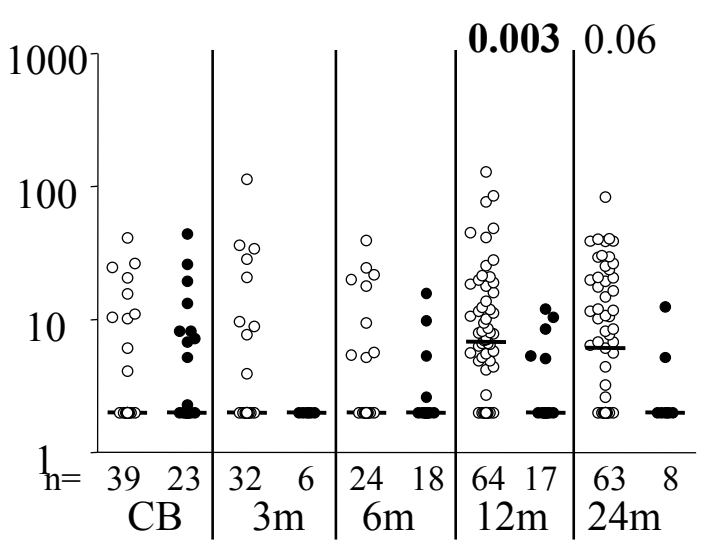

Swe

$\uparrow 3 m \rightarrow 12 m p=0.02$

\section{Birch IL-13}

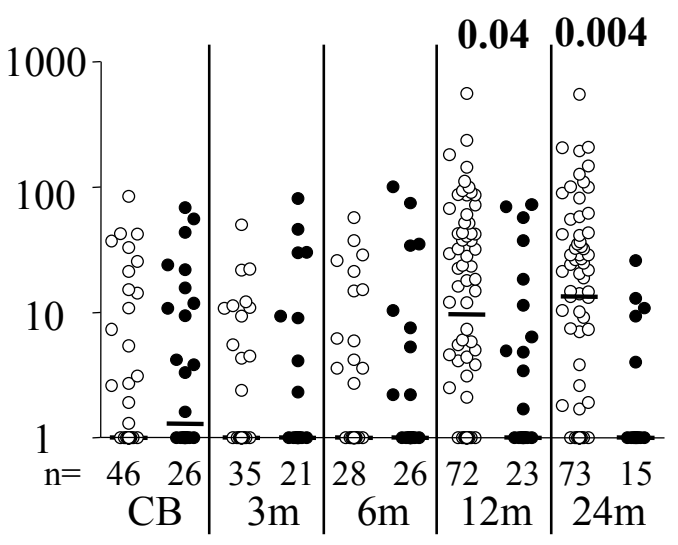

Swe

$\uparrow 3 m \rightarrow 12 m p=0.0001$ 
Fig 4

Birch IFN- $\gamma$

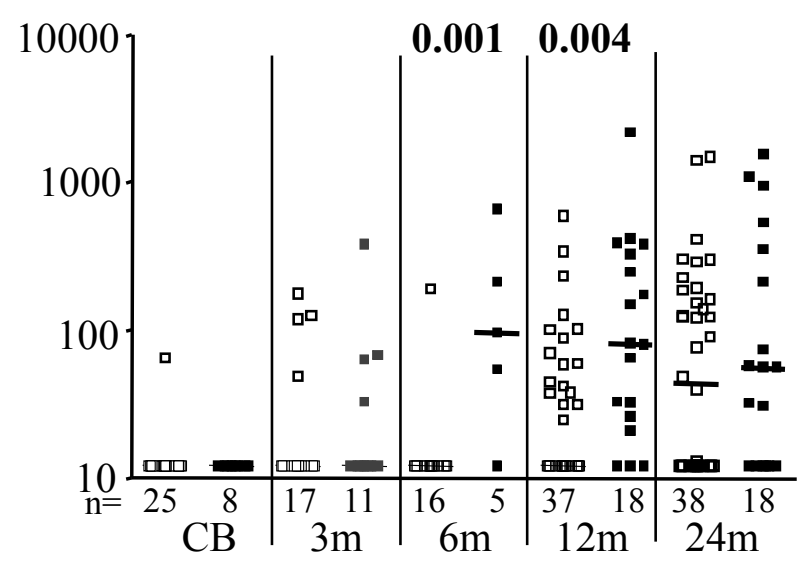

Birch IL-10

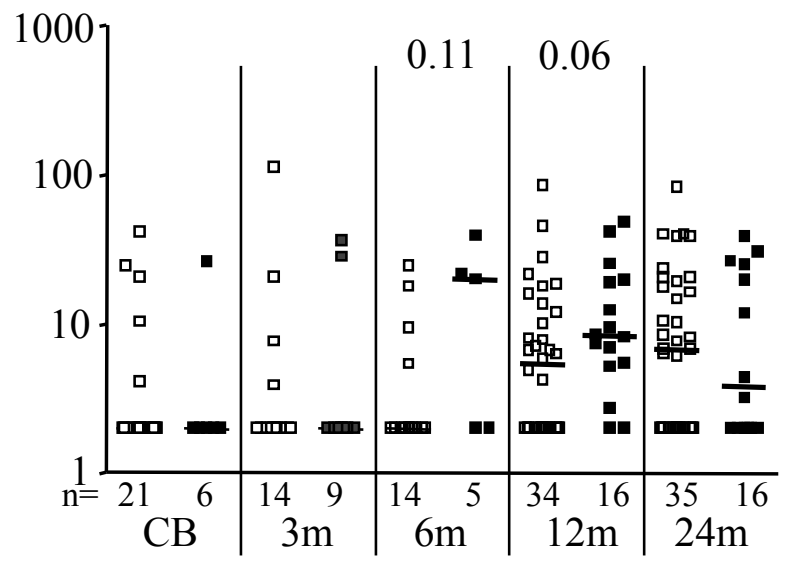

Birch IL-5

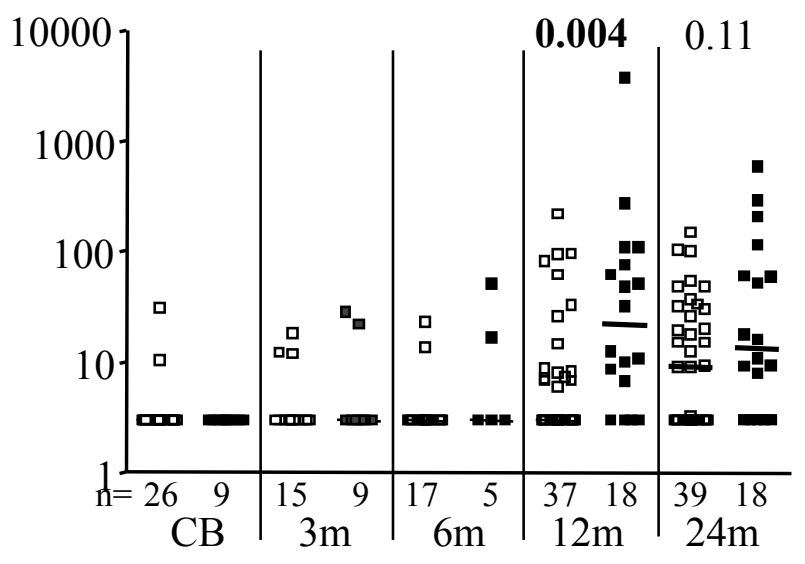

Birch IL-4

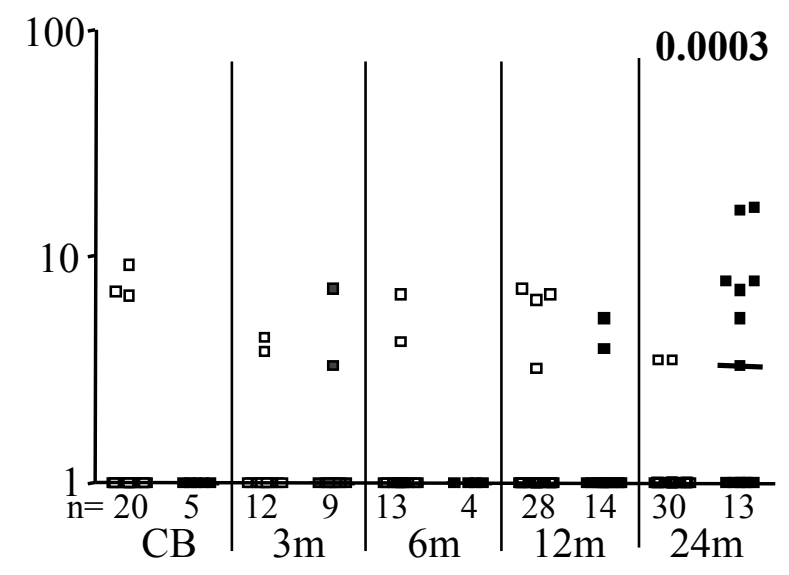

Birch IL-13

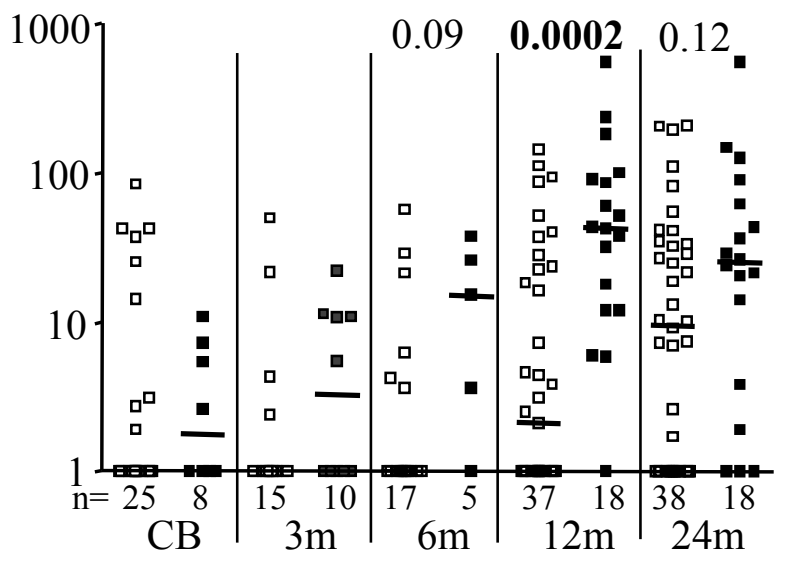

Birch IL-9

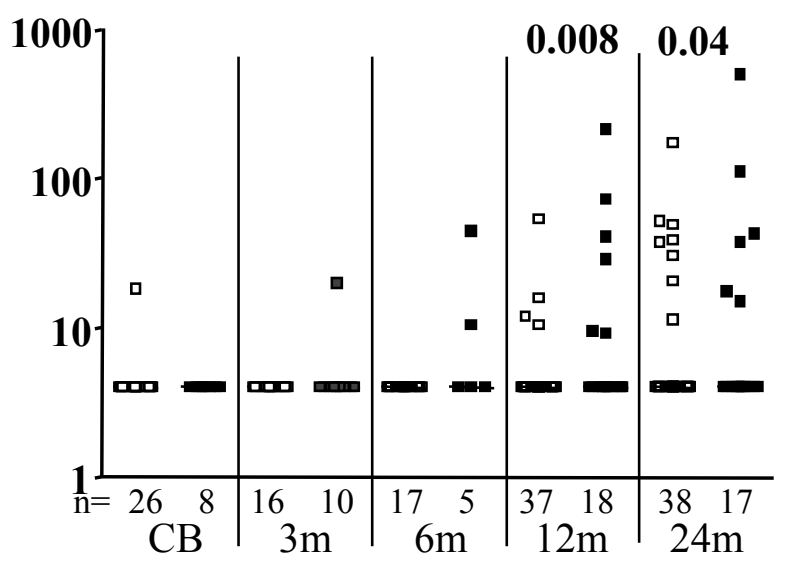

